\title{
The Role and Impact of the Bazaar of Tehran on the First Constitutional Parliament
}

\author{
Hamid HajianPour ${ }^{1} \&$ Mehdi khaksarkahangi ${ }^{2}$ \\ ${ }^{1}$ Assistant Professor, Department of History, Shiraz University, Shiraz, Iran \\ ${ }^{2}$ PhD Student, Department of History, Shiraz University, Shiraz, Iran \\ Correspondence: Mehdi khaksarkahangi, PhD Student, Department of History, Shiraz University, Shiraz, Iran.
}

Received: June 19, 2017

doi:10.5539/jpl.v10n4p239
Accepted: July 19, $2017 \quad$ Online Published: August 30, 2017

URL: https://doi.org/10.5539/jpl.v10n4p239

\begin{abstract}
According to the Iranian Constitutional Constitution, the parliament was considered as the foundation of Constitutionalism and was supposed to realize the most important goal of the Constitutionalists, namely controlling the absolute power of the Shah through defining a recognized law and supervising its enforcement. Such a process took place in Iran and Constitutional Revolution was a product of it. The present paper is trying to investigate the role and impacts of Tehran's Bazaar (market) on the first Constitutionalist parliament. In doing so, after fully describing the context of the study, the required data is gathered through descriptive - analytical approach. The findings of this study show that members of the Tehran's Bazaar is in line with the different social groups, by pressuring the Shah of Iran forced him to acknowledge their demands and played a considerable role in establishing the first Constitutional parliament of the country.
\end{abstract}

Keywords: constitutionalism, parliament, Iran, Bazaar

\section{Introduction}

Constitutional Revolution was the first move to set up a state on the basis of the new institutions to meet the needs of power and social classes affected by developments inflicted on half of the nineteenth century community of Iran, with its most important achievement was the creation of institutions promising traditional power structure change. According to the spirit of the Iranian Constitution, the parliament is the basis of the Constitution that must exercise law as the main concern of the Constitutionalists to harness the power of the king, through the definition of the order, namely the law and monitoring its implementation. Such a process occurred in Iran with the Constitutional Assembly as the main outcome. Assembly was to establish order in the country and consolidate the position of the legislative power to the executive power. This was a difficult and dangerous task, because they autocratic institutions and agents of tyranny remained intact. First Assembly opened in October 1906. The National Council, the most important symbol of the establishment of the Constitutional system and the main achievement of the Iranian Constitutionalists began its work by holding Tehran sixty elected and appointed lawyers. The assembly was composed of trade-class privileged individuals, but major representative were marketers, including merchants and traders.

\section{First Constitutional Assembly and the Role of Tehran Bazaar}

The House of Representatives idea first was introduced by Amin al-Zarb during Qaja in the form of traders House of Representatives, but the failure of the institution and awareness of Tehran marketers of developments in European countries determined them to seek for establishing the Assembly. Following the merchants beaten by Eyn-ed-Dowleh led Tehran Bazaar marketers to close the shops and hold a meeting in the Shah Mosque with the mass of the people (Malekzade, 1992, p. 263). The next day, the protests continued and the protesters demanded for Eyn-ed-Dowleh dismissal as well as the establishment of an assembly to address the complaints of the people. Mozaffar ad-Din Shah realized the adversity of the situation following clergy's immigration to Qom and unwavering support for the Tehran Bazaar Din Shah and decreed for the establishment of house of justice for the first time, reading: "And the establishment of the state House of Justice to enforce sharia subjects is obeyed and comfort of the nation is any major purpose of necessity. We decree that to run these holy intentions, Islamic justice law including sharia legislation is practiced all across the country as soon as possible, so that no one right would be ignored" (Kasravī, 1972, p. 71). Accordingly, Nazim al-Islam adds marketers and money changer guild 
demand of all bills paid and used the term of "establishment of the parliament the right way" instead of the word Dar al-Shura. However, traders in their final demand changed the term "state house" and replaced it with the term "public house" and even strikers Embassy sent messages to clergies in Qom not to quit the strike and stay by side of people until of the Constitution is established (Kermani, 1983, p. 374). Negotiations held between business leaders Haj Hossein Agha Amin al-Zarb, Mohammed Ismail Agha Tabrizi, Mohammad Ali Shalchi, Abdul Razagh Oskoee, Mohammad Taqi Shahroudi, Mohammad Agha Saraf, Mohammad Moein al-tojar Bushehri, and Seyed Mohammad Bagher Kashani and King and the Chancellor. The state appoints them to negotiate with the strikers but, in a meeting with Eyn-ed-Dowleh clearly stated that strikers demand a House of Representatives of the Nation and that they are in the same boat, but did not go on strike for some advantages. However, the Chancellor assumed to meet all businessmen demands. Eventually, the King decree to allow the formation of a national assembly of elected representatives from different social groups was issued (Kermani, 1983, p. 374) that: as decided the National Assembly of elected princes, scholars and Qajar and Lords and nobles and merchants and business owners shall be held in Tehran. Thus, a system of parliamentary elections was set based on Tehran movement and election was held. the House of Representatives of 50 representatives, including 4 princes, 7 grandees, 18 business owners, 3 landowners, 4 clergymen, 13 craftsmen and 1 Zoroastrians (Malekzade, 1992, p. 168).

\section{Social Origin and Class Position of the Representatives of the First Term of the National Assembly}

The number of 161 elected members in the Parliament consisted of 57 (more than a third of the representatives) businessmen, 28 merchants, 29 guilds, 47 (or about 29 percent) clergies, 36 (or about 22 percent) agents of the court, 8 (or 5 percent) Qajar princes and 13 others nations other social classes (Ashraf, 2008, p. 119). In the first House of Representatives' negotiations, Tehran Bazaar and merchants representatives negotiated a total of 1610 times and other guilds representatives negotiated a total of 1214 times on various issues. Six representatives of merchants talked 50 to 400 times with overall 1492 cases of expression of ideas. Participation in raised issues is about 93 percent of the total number of the businessmen speak up issues. The participation of Tehran Bazaar representatives at First Assembly is as follows: Mr. Yazdi traders representative (414) times, Haji Mohammad Ismail Maghazeie (322) times, Sheikh Mohammad Taqi Vakiloroaya Iran (300) times, Haji Agha Mohammad Bushehri (229) times, Haj Hussein Agha Amin al-Zarb (117) times, Adib Tojar Esfahani (56) times, and Haji Mohammad Taghi Bonakdar (54) times. The statistics alone show the role of Tehran Bazaar in parliament in (Ashraf, 2008, p. 120).

Tehran merchants and traders were very active in parliamentary elections, members of the Supervisory Board started work on 10 Sha'ban 1324 AH with the perceptible presence of Tehran traders and merchants among representatives of other groups in the Board of Supervisors. Haj Seyyed Mohammad Tajer and Haj Mohammad Ibrahim were two traders and merchants supervisors, and in other provinces the traders and businessmen acted the same fighting the states secret conspiracy to stop the election. Businessmen and traders activity was so serious that triggered protests in their performances (Bashir, 1984, p. 14). the most active traders of Tehran during the Constitutional Revolution were elected as merchant class lawyers in the National Assembly; Haj Ismail Maghaze, Seyed Morteza Mortazavi, Haj Agha Moein al-tojar Bushehri, Mirza Mahmoud Tajer Isfahani, Haji Mohammed Ali Tajer Shalforosh, Mirza Hassan Khan Vosuq al-Dowleh, Haji Mohammad Taghi Tajer Shahroudi, Mohaqq al- Dowleh (political school principal) and Mohammad Gholi Khan Mokhber al-molk. According to the statute and in accordance with Article VI, the share of Tehran classes of legislators was marked: princes and Qajar: 4, clergies: 4, traders 10, landlords and peasants: 10 traders of any tier: 1 (a total of thirty-two). In other words, $21 \%$ of the representatives included privileged classes and the owners, $25 \%$ of the ranks of Clergymen, and 26 percent of the guilds. Merchants, in addition, its majority share, acted as other advocacy groups, especially unions and religious minorities; Haji Mohammad Taghi Bonakdar, the active businessman of the migration times as the merchant class Constitutional lawyer. Amin al-tojar Kordestani and Haj Mohammad Taqi Tajer Dehbandeh and Arbab Jamshid included other businessmen elected by the other guilds. The reason behind their selection was that they were considered more aware of the issues with the knowledge that we have no one among themselves better than them (Afari, 1946: Iranian Constitutional revolution, p. 14).

Amin al-Zarb was very active in the formation of a Constitutional institution, the National Assembly and was introduced to Parliament as representative of the Tehran businessmen. He and other Constitutionalists tried to resolve different problems during the first two years. Amin al-Zarb was the second vice president of the parliament and joined the majority of the Finance Commission and the Commission and the Foreign Ministry in an attempt to resolve issues and relations between Parliament and the relevant ministries. He is among those who were present in writing the Constitution and most likely principles of corporate security and internal power against foreign domination and tax issues and security of capital were proposed by him. At the time of 
introduction of attempting to establish a bank, Amin al-Zarb was among those bank funders and his shop was the place to purchase bank stock and always was conscious and most progressive legislators and a supporter of the Constitution during parliamentary hearings (The Shah of Iran, 1946: issues related to Amin al-Zarb). Mohammad Taghi Bonakdar, another prominent Tehran Bazaar merchant after the issuance of the Constitution, in recognition of his services in cooperation with the Constitutionalists was elected to represent the National Council. Haj Ismail Maghazeie was elected in Tehran parliamentary elections by businessmen and was among the most active traders in Parliament. He was the second progressive trader participating in the greatest speeches in support of the establishment of banks and raising the issues of security of people and disturbances on Governors and Finance and Justice Issues performances. He was a member of Domestic affairs and Financial Commissions to resolve the related issues. He was the reference for financial issues by people in the parliament always complained about continuing traditions of the tyranny of the court and the states' rulers. He called for accountability in the related to ministries' issues negotiations and tax settings as well as remove the foreign domination in the Council of Ministers. At the beginning of Amin al-sultan cabinet work, in Parliament he warned him that the Parliament will not tolerate any shortcomings arise in progress (The first Parliament negotiations, p. 267). Moein Al-tojar Bushehri was a Tehran Bazaar prominent merchant who played a key role in the First House. Haji Moein was introduced in the National Assembly as a lawyer in Tehran merchant class to Parliament. He was conscious businessmen and legislators in political and economic affairs. In the first debate of the Assembly on the issue of borrowing from the government of Russia and England, first in an enlightened speech, he scientifically refused loans from foreign rule and proposed to meet cash needs for reforms with the help of the people and defused government forces in several meetings and thus the National Bank was established in Zihajh 1324 AH (The first Parliament negotiations, p. 6). Moein al-tojar commented on resolving tax issues and the dominance of Foreign Affairs as well as demanding for Justice and securities in the Parliament and the Commission's, and was of the most liberal merchants. He, for his efforts in support of national economic plans and political independence of foreigners faced with the conspiracy, including banks.

\section{Tehran Bazaar Measures in the First Assembly}

The role of Tehran Bazaar in the elimination of foreign dominance: the first cooperation and relationship between government and parliament were on a bill giving the government the right for borrowing from both Russian and British governments. The government sent plans to borrow money from foreigners to face the crisis in the early days of Constitutionalists (Kasravī, 1972, p. 205). According to the bill, borrowing jointly from the two governments to meet court expenditure, unpaid troops and unexpected spending with warning the governments urgent need of the money. The initial reaction of the representatives for the government's request was two; some voted: it is ok because the government needs the money, and it is only for one year, and then after a year, they will not exert any force on us. Another group of representatives asked the government to provide the Parliament with the list of debts and expenses to avoid misappropriated (Kermani, 1983, vol. 2, p. 4). Both deployments in dealing with such an important issue of bonds, was superficial and uninformed. Moein al-tojar in his speech to dismiss all the Articles of the Agreements said that the government is not at all in debt because Prince Atabak said that he balanced government spending and brought six hundred dollars extra. The government must send to parliament three-year spending to be inspected. If the government is in debt, it should be addressed, but not for a hundred crore money the country surrenders to foreigners. This information of government expense is not because of the four hundred crore, but the government needs at least a hundred crore for reform (Kasravī, 1983, p. 185). Therefore, Tehran Bazaar efforts could save the country from dependence on foreign and adopting negative balance policy overcome domestic economic crisis through the establishment of banks and the domestic bond.

Tehran Bazaar traders and merchants attempt to establish the National Bank: According to merchants in Tehran and guilds country is not ordered unless by wealth and prosperity achieved through security and thus there is an urgent need for the National Bank establishment. We did not negotiate any other issue except the National Bank establishment since the royal command decreed on and a number of 50 representatives, including (15) clergies, government administration staff (10), Zoroastrians (12), Armenians (2), merchants (6) and scientists (10) have presented the quality and the quantity of the issue to negotiate out and after investigation and scrutinized issue on what appropriate for the country. Therefore, the representatives of trade unions, together with merchants' representative based on the historical mentality believed that both the Russian government and the United Kingdom do not lend anyone without any benefit and so as they conditioned lending on the control of customs of the North and South. But after much discussion in the House, the bill on foreign borrowing was rejected on the idea of establishing a National Bank (Kasravī, 1983, pp. 23-27) with the majority of positive votes. Rejected the bill the government, Merchants made efforts in providing the grounds for the establishment of the National Bank 
through the collection of financial aids from the states, they sent telegrams to states and major big cities traders, with the support and promotion of Tehran Habl al-matin newspaper calling for a public campaign to establish a National Bank that was called "nationalist fervor against alien" to preserve nation gold from being sent abroad. Merchants, in a telegram, announced the Bank establishment and shops of prominent businessmen in Tehran was determined as the place to purchase bank shares, Mohammed Ismail Maghazeie shop, and Agha Saraf Tabrizi, Arbab Jamshid, and Tomaniansis shop. The name of banking founders was announced. the founders of the bank determined as the following: Amin al-tojar Kordestani, Mr. Haji Mohammad Amin al-zarb, Haj Mohammad Moein al-tojar Bushehri, Haj Ismail Tajer Tabrizi, Haji Mohammad Ali Shalforosh, Haji Mohammad Ibrahim Malek al-tojar Isfahani, Agha Mirza Mohammad Shafi Malek al-tojar, Haji Mohammad Hossein Kazerouni resident of Isfahan, Haji Mohammad Qazvini, Haj Faraj Agha Saraf Tabrizi, Haji Rabi Agha Tajer Tabrizi, Hajibagheri Agha Saraf Tabrizi, Haji Mirza Abasgholi Agha Tajer Tabrizi called Etehadiye, Haji Mohammad Taqi Tajer Shahroudi, Haji Mirza Ali Saraf Isfahani, Haji Mirza Ali Akbar Rough Tabrizi, Moavn al-tojar Dehdashti, Haji Moshyraltjar Mohammareh, Agha Mohammad Sadiq Dehdashti, Haji Mirza Ahmad Tajer Lar Shirazi, Haji Seyyed Mohammad Shabankareh and Akhavan in Bushehr, Haji Mirza Hasan Shirazi, known as Shalforosh, Haji Mirza Yaqub tajer Amin Qazvin, Mohammad Agha Company Iraqi, Agha Mohsen Agha, Omda al-tojar Arbab Jamshid, Omda al-tojar Tomanians. Though Tehran Bazaar merchants' attempts could not gain the desired results through domestic and foreign sabotage their efforts are considered critical.

\section{Trying to Pass the Constitution}

Merchants and Trade union associations knew the misery of the past due to lack of Constitution and made efforts, leading to revolution. Associations in the bill noted that the basic problem remains unresolved referring to the amendments to the Constitution, "We don't know why, it is the recently passed Constitution be written and the amendments for as compliance with the law of Islam, has been put into effect and there were only minor differences in the two seasons that were corrected, the Constitutional principles are subject to publishing and implementation, but despite so much public anxiety and excitement regardless of chaos in the country, it is not implemented, yet. And Constitution that was of the main purposes of the Parliament is silent while now the nation faces much of the misery and we ask for this misery elimination". Associations also asked the Parliament the completion of the amendment to the Constitution to the end of the month of Rajab 1325. Therefore, the Constitution was one of the main Tehran Bazaar representatives and trade unions in Parliament demands. However, there were differences in opinions on the amendments from the beginning, since religious leaders were trying to formulate the principles of law according to their own vision, while some intellectuals and scholars made efforts to increase national power following the rules of some European countries and a number of princes, courtiers encouraged the increasing the power of the king in the new political regime. But then the Constitution adopted on December 29, 1906, and King signed it with Tehran Bazaar merchants played a very important role in its adoption. Review some of the principles well shows the role of businessmen and merchants in Tehran. In a session held in 7 Rajab AH., businessmen in parliament dealt with the Constitution and the law and their relationship to each other's; Vakil al-tojar Yazdi said "The law defines the monarchy borders, consolidates Constitutional principles and puts ministers responsible, runs Islamic laws, orders and organizes the country to honor of people in safety and security. He also referred to some tyrants vilifying in the disguise of Constitutional lawyers and ministers. Mohammad Ismael Maghazeie called the ministers' absence from the parliament in the fear of evil villains. At this meeting, the importance of laws was considered to be the root causes all of these causes (Avari, 1984, p. 169). In 14th Zilghade, Constitution was read by the parliament, with some of the Articles specifically to resolve trade issues, including Articles 15 and 17 of the Constitution on the principle of security of property against the threat of powerful domestic authorities with any matters relating to property taxes will be only subject to the law and not the custom and former government officials intentions. According to Article 15 , no property may be seized without the permission of the legal owner and it shall be owned only after determined fair price is paid. Article 16 prohibited confiscation of the property of the people as punishment and policy unless it is in accordance with the law. Article 17, prohibited stripping control by guardians and owners of the properties or to any other title, unless by law. This Article is based on the fear of confiscation of the property by rulers and authorities. The content of 22 to 26 of the Constitution is to protect corporate security against the threat of foreign domination and influence. The principles are subject to the approval of Parliament in granting any concession of trade and industry. The Article 23 required company's establishments for public companies and or any title not to the government, but legislative approval. The Article 24 read that treaties and conventions and concessions to the interior and foreign trade and industry approval were transferred to Parliament. The Article 24 entitled the government to gain Parliament approval in cases of borrowing from domestic or foreign entities. Amendment of the Constitution, Articles 94 and 100 include the discussion of the tax law and regulation as one of the main business concerns. Based on these principles, toll and the implementation of all aspects of 
business tax are only on the basis of the law, Article 94 reads: "No tax shall be imposed except as provided by law." In the past, traders exempted from tax and only subject to one kind of duty, but actually paid ten to twelve times more toll on customs and even did not enjoy the same rights with sovereign foreign states businessmen; these were the factors that caused disability in competition with foreign trade followed by economic decline.

Article 95 had predicted that the tax-exempt items can be determined and Article 96 was approved that the tax amount shall be determined by the National Assembly with a clear majority annually. Board states that Parliament focuses on areas controlled by the state for a profit without consideration of domestic trade and its operators, bought from any area not under the supervision of the Central government (The House newspaper).

According to Article 97 of Amendment there shall not put any distinctions among citizens and this principle has been emphasized on equality in the Constitutional system. Article 98 knows any discount and exemption of taxes under the law. Article 99 reads that people would be demanded nothing by no means only in the name of, state and provincial and municipal taxes and the 100 amendments to the Constitution reads transfer of all conventional and tips to treasury shall be only by law (Blue book, 1984, p. 107). Review the Constitution shows the important role of Tehran Bazaar in the formulation and adoption of the Constitution.

Attempt to form the Ministry of Commerce: Secretary of Commerce in the House presented a bill to parliament, given the importance of trade as a source of wealth and the greatest power of any country indicating Iranian trade was not based on science, but only based on experience and it is limited. Iran's image of businessman means the person who exports and imports goods. Minister believed this image was a wrong impression and the trading companies should be funded. He believed science-based trade rules based on accurate and true principles must be applied in the country. This does not change by hiring some knowledgeable advisors, but because trade is in the hands of traders, merchants must have change and progress in science. The minister proposed solutions that addressed a Business School in Tehran for merchants to send their children to study science and chemistry and bookkeeping and business documents to have wealth of information and knowledge. In this bill, the Assembly was asked to ratify Business School established the annual spending of Three thousand five hundred Toman intended to teach a trade minister in the Ministry of Commerce branch. The bill was approved in the Committee of Finance with the participation of businessmen and Vakil al-tojar and Moein al-tojar knew this action boosts. In fact, the Ministry of Commerce formation during the Constitutional was to regulate affairs. The ministry existed during Nasser, but lacked progressive role and only dealt with commercial disputes. During the Constitutional, attempts were made to work only on development of agriculture and industry with the separation of commercial disputes settling down from the ministry. A large number of MPs to the National Assembly were merchants. The representatives did their duty with faith did not stray out of the right way and legislation that the First House passed laws were consistent and best laws under the Constitution. Constitution revolution politically increased the power of the merchant class.

Financial regulation: Another merchant of Tehran measures in the first parliament was to settle down tax issues. They believed the main causes of disturbances and abuses in stated were tax and the ruler's attitude that sought to make Constitutional crisis more difficult. They, using old methods forced people to pay duties and taxes without and receipt and whatever money was spent on the site to their liking.

Parliamentary hearings discussed over taxes and governors pretexts that if the Minister of Finance and Minister of Domestic affairs are dissatisfied with the rulers and their performance in finance, they will be changed by Parliament (The Imperial Iranian official newspaper, 1946, p. 5). Merchants insist on tax reform led to the provision of tax bill to regulate tax system. The bill addressed three to solve the problems, including maintaining order, the upbringing of children and facilitate communication on country roads. The bill provided provisions for past issues such as merchant's insecurity from bandits and delays in business due to the distances between regions, and policy and strategy and merchants in the House supported proposal on the necessity of establishing a railroad and even Vakil al-tojar Yazdi and Mohammad Ismail Maghazeie asked increase in tea and sugar taxes to develop roads to reduce transportation costs and boost trade provided that the funds will be given to the Ministry of Finance for public and business use. They knew roads development a way to reduce transportation costs and trade promotion (Parliament negotiations, 1857, p. 4-20).

\section{Conclusion}

Based on the article and the evidence presented in the text we conclude that Tehran merchants and traders, in addition to synchronizing with different classes of society and people, excreted the kind of pressure on the government to meet their demands with a significant role in the formation of the first Assembly. Moreover, Tehran Bazaar merchants and traders could establish Constitutional order in the House and consolidate the stance of legislative authority, so far do not existed, against executive authority. The role and importance of Tehran 
Bazaar merchants and trader's participation and influence in the parliament confirmed that they could confront the executive authority who was a tyrannical power. Notably, given the statistics presented in this article most speeches and issues have been raised by Tehran Bazaar merchants and trader's representatives. The statistics alone show Tehran Bazaar merchants and trader's role in the first parliament.

Merchants have always been among the most knowledgeable and the most progressive MPs and supporters of the Constitution, as well as those of the most influential role in writing the Constitution and complement the principles of corporate security and elimination of foreign domination and issues of taxes and enterprise security. Banks were formed by their efforts as well as more bonds were sold by them. Their influence on the financial and domestic commission's provided security and peace of mind for their colleagues as well as others. Another dramatic impact of them was Government and Parliament negotiations on borrowing from British and Russian governments issues to eliminate dependency on the states that it was against the will of the government.

Therefore, Tehran Bazaar efforts could save the country from dependence on foreign and adopting negative balance policy overcome domestic economic crisis through the establishment of banks and the domestic bond.

\section{References}

Ashraf Ahmed, B. A. (2008). Social classes, State and Revolution in Iran. Translation: Soheila Torabi Farsani, Tehran: Nilofar Publishing.

Avari, P. (1984). Contemporary history of Iran. Mohammad Rafie Mehrabadi, Tehran: Atai Institute of Information.

Blue Book, "Confidential reports of the Britain Ministry of Foreign Affairs about the Constitutional Revolution of Iran", Ahmad Bashiri, (Tehran, Nashre no, Second Edition, 1984, Volume 7, pp. 13-14). Habl al-matin newspaper, (the fourteenth year, 26 Muharram 1325 AH. / 11 March of 1907), No. 29

Kasravi, A. (1972). Constitutional history of Iran (9th ed.). Tehran: Amir Kabir.

Kermani. (1983). Iranian wakeup call history. vol. 2, p. 374.

Malekzadeh, M. (n.d.). History of the Iranian Constitutional (3rd ed.). Ali Press, p. 263-1992.

The Imperial Iranian official newspaper, Director Seyyed Mohammad Hashemi, the First House of Representatives negotiations, 1946, issues related to Amin al-zarb.

\section{Copyrights}

Copyright for this article is retained by the author(s), with first publication rights granted to the journal.

This is an open-access article distributed under the terms and conditions of the Creative Commons Attribution license (http://creativecommons.org/licenses/by/4.0/). 